\title{
Wel of niet resultaatgericht inkopen: twee visies
}

\section{$\underline{\text { Tim Robbe, Jan Telgen, Niels Uenk }}$}

De decentralisatie van zorgtaken in het kader van de Wmo 2015, Jeugdwet en Participatiewet naar gemeenten heeft als doel om in deze zorg meer op de individuele cliënt toegesneden maatwerk te bieden. Gemeenten kunnen dat doel onder andere bereiken door hun relatie (als opdrachtgever) met aanbieders van deze zorg op een bepaalde manier vorm te geven in de contracten. Dit noemen wij "opdrachtgeverschap". Momenteel kopen gemeenten zorg vooral in op basis van output fproductenuren zorgt van een bepaald niveau. Een alternatief is het inkopen op basis van resultaat foutcome). Momenteel voeren expertso-discussie over de toepasbaarheid en wenselijkheid van contracten die resultaten centraal stellen is discussie, waaraan wij prominent deelnemen met verschillende visies. In dit artikel zetten wij de standpunten en argumenten uiteen. Na een korte definitie en uitleg van resultaatgericht inkopen geven Niels Uenk en Jan Telgen geven de argumenten vorvóór resultaatgericht inkopen. Tim Robbe geeft de tegenargumenten. In andere artikelen in deze inkoopspecial van Sociaal Bestek werken de auteurs hun eigen aanpak verder in detaituit.

\section{Wat verstaan we onder resultaatgerichte inkoop?}

Gemeenten gebruiken in het sociale domein verschillende termen voor inkoopbenaderingen van zorg die zicht richten op een te bereiken resultaat: prestatiecontracten, resultaatbekostiging, resultaat gerichte inkoop, et cetera. Wij gebruiken de term resultaatgerichte inkoop of resultaat bekostiging voor contracten waarin de te bereiken resultaten centraal staan. Deze contracten laten de wijze waarop zorgorganisaties de resultaten bereiken vrij voor invulling door die zorgorganisaties. Bij resultaatbekostiging kan de vergoeding (tenminste voor een deel) afhankelijk zijn van de mate waarin het resultaat is bereikt via een bonus-malus regeling. Resultaatgerichte inkoop in deze strikte vorm komt in het sociaal domein niet of nauwelijks voor. Veel meer zien we contracten die het te bereiken resultaat definiëren, en hier een vaste vergoeding tegenover stellen.

\section{Niels Uenk en Jan Telgen: argumenten voor resultaatgerichte inkoop}

Een eerste argument vóór resultaatgerichte inkoop is bijna filosofisch van aard. De zorg en ondersteuning draait uiteindelijk niet om de inzet van zorgaanbieders, maar om wat het oplevert. Als je je huis laat verven, ben je ook niet geïnteresseerd in de hoeveelheid uren die schilders besteden: je wilt een huis dat weer netjes in de verf zit. In het sociaal domein draait het om zelfredzaamheid, zelfstandig thuis kunnen blijven wonen, sociale contacten, enzovoorts. Inkopen van resultaten stelt datgene centraal waar het uiteindelijk allemaal om draait: zelfredzaamheid en participatie. Als resultaten centraal staan komt men los van discussies over uren zorg - een systeemwereld - en komt men dichter bij de werkelijkheid: de leefwereld van burgers.

Een economisch argument om resultaten in te kopen in plaats van uren, is dat het zorgaanbieders prikkelt en faciliteert om op slimme wijze - mogelijk met nieuwe zorgconcepten en nieuwe technologieën - de resultaten te bereiken. Dit in tegenstelling tot een bekostiging die productiedraaien beloont, waarin innovatie eerder afgestraft wordt dan gestimuleerd. Een simpel voorbeeld: een zorgaanbieder die per uur betaald wordt en 3 uur individuele begeleiding per week mag leveren heeft geen enkele aanleiding om dat te vervangen door dagelijks 10 minuten beeldbellen met de 
cliënt, zelfs als dit net zo effectief is. Hij zou alleen maar omzet gaan mislopen. Voor een zorgaanbieder die een vast bedrag betaald krijgt om een resultaat te bereiken ligt dat anders: iedere innovatie die effectief is zal hij inzetten om een betere zorg te kunnen leveren en een betere bedrijfsvoering te realiseren.

Naast het economische argument is er ook nog een inhoudelijk argument: resultaatgerichte inkoop geeft optimale vrijheid voor zorgaanbieders om samen met de cliënt te bepalen hoe zorgverlening het beste kan worden ingericht: doen wat nodig is, wanneer het nodig is, meer niet. Tegelijk houdt de gemeente grip op het 'wat': per cliënt wordt een goede afweging gemaakt van de resultaatgebieden waar ondersteuning nodig is, en de gemeente houdt zicht op de resultaten. Bovendien hoeft een zorgaanbieder bij een resultaatgerichte systematiek geen tijd meer te besteden aan het bijhouden en richting gemeenten verantwoorden van geleverde uren: een activiteit die geen waarde toevoegt aan het zorgproces.

Tenslotte is er een meer dan subtiel verschil in de verantwoordelijkheden: bij inkopen van uren moet de gemeente / het wijkteam bij de toegang goed kunnen bepalen hoeveel uren nodig zijn. Zij gaan dus eigenlijk op de stoel van de zorgaanbieder zitten en de zorgaanbieder wordt gedegradeerd tot uitvoerder. Bij resultaat gerichte inkoop wordt bij de toegang alleen het te bereiken resultaat gedefinieerd en wordt het aan de professionals (de zorgaanbieder) overgelaten hoe dit resultaat het beste bereikt kan worden.

Wij horen vaak als tegenargument: de causale relatie tussen dienstverlening en resultaat is in het sociaal domein doorgaans niet aangetoond. Dit zou bekostigen van resultaten niet mogelijk maken. Wij betogen het omgekeerde: als het verband tussen dienstverlening en resultaat onzeker is, dan moet je juist geen uren dienstverlening inkopen, want dan heb je geen zekerheid over het resultaat. Dan moet je juist resultaten inkopen. Afspraken over de resultaten leveren de cliënt méér zekerheid op, zolang de resultaten te meten / observeren / ervaren / waar te nemen zijn.

\section{$\underline{\text { Tim Robbe: argumenten tegen resultaatgerichte inkoop }}$}

Uiteraard draait zorg en ondersteuning om de individuele hulpvrager en zijn gewenste resultaten. Dat staat buiten kijf. De vergelijking met de schilder gaat echter opeen aantal punten-mank. Ten eerste maakt het mij wel uit hoeveel uur een schilder bezig is met verven. Er kunnen ook andere dan financiële belangen meespelen. Als ik mijn huis wil verkopen over een maand, dan heb ik er weinig aan als de schilder er twee maanden over doet. Dan wil ik dat hij binnen een maand gereed is. En dat heeft direct gevolgen voor het aantal uren dat hij mag besteden. Verder is $\underline{H}$ het resultaat "een huis dat netjes in de verf zit" is makkelijk te meten en is ook het verband tussen de werkzaamheden van de schilder en dat resultaat makkelijk vast te stellen. Dat is voor wat betreft de inzet van hulpverleners en de verbeterde zelfredzaamheid of participatie van hulpvragers heel anders. De resultaten van de hulpvrager moeten dus wel centraal staan, maar op het juiste niveau: bij die hulpvrager. De inkoop gebeurt tussen gemeenten en zorgorganisaties en niet op het niveau van de hulpvrager. Inkoop is juist onderdeel van de systeemwereld. Door daar al over resultaten te spreken voor individuele hulpvragen vindt per definitie een versimpeling plaats van de werkelijkheid. Uiteindelijk gaat dan de inkoop de leefwereld van burgers in de weg zitten: de hulpvraag moet

Commented [JT1]: Ik zie niet in wat dit met het verschil in benadering te maken heeft: ook bij resultaatgerichte inkoop kun je stellen dat het binnen een maand klaar moet zijn 
passen in de bij de inkoop afgesproken hokjes. Dat moet eigenlijk andersom als je echt wilt aansluiten op die leefwereld.

Voor wat betreft het economische argument: de praktijk laat niet zien dat het inkopen van resultaten in het sociale domein leidt tot innovaties. Tot op heden zien wij bij gemeenten die bijvoorbeeld een "schoon en leefbaar huis" inkopen, dat dit vooral leidt tot minder uren zorg en de inzet van steeds lager ingeschaald en geschoold personeel. De reden hiervoor is dat het bedrag dat een aanbieder krijgt voor het bereiken van het resultaat teruggerekend wordt naar uren inzet en dan vaak leidt tot een te lage kostprijs per uur om personeel te betalen. Innovatie met minder geld slaat door naar overleven. Voor werkelijk innovatie is niet per se bekostiging per uur nodig, maar wel bekostiging voor de innovatie an sich. Je zou bijvoorbeeld een prijs kunnen afspreken voor zowel een uur begeleiding als een uur beeldbellen.

Het is de wettelijke verantwoordelijkheid van de gemeente om vast te stellen wat de hulpvrager nodig heeft. Het is helemaal niet wenselijk dat de zorgorganisatie (al dan niet samen met de hulpvrager) besluit hoe de zorg het beste in te richten. Er is sprake van een afhankelijkheidsrelatie en waarschijnlijk een kennisachterstand. De gemeenten hebben dan ook de taak de hulpvrager te beschermen bijvoorbeeld door rechten en plichten aan zowel de zorgorganisatie als hulpvrager toe te kennen. Om dit goed te kunnen is wel meer deskundigheid nodig aan de zijde van de gemeente. Dat die er (nog) niet is, betekent niet dat we dan maar zorgorganisaties vrij spel moeten geven. Feitelijk gezien zullen zorgorganisaties bovendien uren blijven registreren, al is het alleen al om aan arbeidsrechtelijke verplichtingen te voldoen. Of om in de Wmo 2015 goed mee te kunnen werken aan een eigen bijdrage regeling.

Met voldoende deskundigheid bij de gemeentelijk toegang, kan deze op individueel niveau een resultaat formuleren dat past bij de betreffende hulpvrager. De gemeente gaat dan samen met de hulpvrager "shoppen" bij zorgorganisaties die dit resultaat denken te kunnen leveren. De zorgorganisatie is in dat scenario geen "uitvoerder", maar expert die aangeeft hoe hij denkt het resultaat te bereiken. De inkoop hoeft daarvoor (juist niet) op resultaten plaats te vinden. Veeleer is de waardering en bekostiging van die deskundigheid nodig.

Tot slot is het juist nodig wat anders in te kopen dan resultaten als ik het causaal verband tussen resultaten en interventies niet kan aantonen. Het behalen van resultaten is namelijk per definitie onzeker in het sociale domein. De hulpvrager heeft bij een deskundige inzet de meeste kans(!) dat de zorgverlener de gewenste resultaten bereikt. Hoe hoger die deskundigheid, hoe beter deze om kan gaan met het grillige verloop van een hulpverleningstraject. Het is dus zaak juist die deskundigheid in te kopen en het formuleren en bereiken van resultaten over te laten aan de individuele casuïstiek.

\section{Mag resultaat gericht inkopen?}

Vanaf 2014 zijn verschillende gemeenten die een resultaatgerichte systematiek gebruiken in hun indicatiestelling op de vingers getikt door bestuursrechters. Het ging daarbij vooral om huishoudelijke hulp met resultaatgebieden als een 'schoon en leefbaar huis'. Deze uitspraken gaan over de relatie hulpvrager en gemeente (de beschikking) en niet over de relatie zorgverlener en gemeente (het contract). Tussen zorgverlener en gemeente is het inkopen van resultaten juridisch 
zeker mogelijk. Of het verstandig is, is afhankelijk van de vraag welke argumenten de lezer doorslaggevend vindt gezien de in dit artikel uiteengezette standpunten. 